\title{
The Silver Age of Swedish Education
}

Due to the country's rapid development from poverty to affluence in the late nineteenth and early twentieth centuries, history came to be regarded with mistrust and suspicion in Sweden. ${ }^{l}$ As the author Gunnar Ohrlander has observed about his upbringing during the optimistic and modernizing 1950s, everything old was considered to be "trash" and an unwelcome reminder of the recent hardship. ${ }^{2}$ There was seemingly no point to history and nothing to be learned from it-a sentiment encouraged by the long-governing Social Democrats in their ambition to achieve cultural hegemony, as the historian Åsa Linderborg has demonstrated. ${ }^{3}$ Instead, "progress" became the national leitmotiv. Today, this once partly understandable view of the past as having little to offer continues to pervade attitudes toward many issues in Sweden, not least education.

The general understanding of the old school system is essentially that presented in the movie Torment, set and produced in 1944, in which a cruel teacher inflicts pain on his students when they cannot recite Latin grammatical forms. The scriptwriter Ingmar Bergman, who later became a world-renowned film director, claimed to hate "school as a principle, as a system, and as an institution" and used the movie as a vehicle to express

${ }^{1}$ See, e.g., Englund's (2015) discussion of this point.

${ }^{2}$ Ohrlander (1981, p. 20).

${ }^{3}$ Linderborg (2001).

(C) The Author(s) 2022

M. Henrekson and J. Wennström, Dumbing Down, https://doi.org/10.1007/978-3-030-93429-3_2 
his resentment of organized education. ${ }^{4}$ Over the years, however, the propagandistic aims of the film were forgotten. Instead, Torment came to be seen as an accurate, almost documentary representation of school life in Sweden before the end of World War II and the start of the reforms that led the educational system down the path of "post-truth" schooling. ${ }^{5}$ An iconic black-and-white screenshot from the movie in which the fictional teacher menacingly pokes a terrified adolescent with a meter-long rattan cane, is often used as an illustration of the historical teacher-student relationship in Swedish schools - and, more or less implicitly, as an argument in favor of the postmodern social constructivist educational system.

However, the now established view of the school system that directly preceded the one discussed in this book as mechanical and authoritarian is deeply misleading. During the period between roughly 1860 and 1960, Sweden instead had a (for its time) modern and sophisticated educational system, which we describe in this chapter to dispel the notion that what came before the postmodern social constructivist education paradigm was of little value or even harmful to students-undermining their innate creativity, dulling their motivation to learn, and making them susceptible to authoritarian ideologies. It should, of course, be noted that this system was not perfect. Indeed, we are keenly aware of the danger of falling into the trap of false nostalgia and golden-age thinking. Borrowing from the U.S. educationalist E.D. Hirsch's description of the predecline era of U.S. schooling, ${ }^{6}$ we therefore call this period in Swedish education "the silver age."

\section{The Pedagogy of the Old School System}

The obedience-based education that is depicted in Torment was not an inherent part of the school system to which we refer. The movie's criticism is better directed at the so-called Bell-Lancaster method, which most Swedish schools practiced when formal schooling was first enacted nationwide (in the so-called folkskola) by the Elementary School Act of 1842.

\footnotetext{
${ }^{4}$ See the Wikipedia entry on Bergman: https://en.wikipedia.org/wiki/Ingmar_Ber gman.

${ }^{5}$ We return to these reforms in Chapter 6.

${ }^{6}$ Hirsch $(2016$, p. 6).

${ }^{7}$ For the historical information on schooling in Sweden in this chapter, we draw mainly on Heller Sahlgren and Sanandaji (2019), Lidström (2015), and Andersson (1986).
} 
In this rather primitive and factory-like form of education, older or more gifted students-referred to as "monitors"-transmitted what they had learned to younger or weaker students, while teachers signaled changes between subjects and exercises with whistles and bells and responded to even minor transgressions with corporal punishment. ${ }^{8}$ One example of a monitor was the renowned Swedish painter Carl Larsson (1853-1919). In his posthumously published autobiography, he writes that upon entering elementary school, "I was immediately deemed so knowledgeable that I was - in accordance with the Lancaster system-elected to be a 'monitor' for some puppies even more ignorant than myself, and I did this so well that at the end of the semester I was awarded one daler and 24 shillings." 9

It is clear that by making it "possible for a single teacher, with the help of students who were more advanced and extreme discipline, to impart the legally required education to an excessive number of students," the Bell-Lancaster method offered economic benefits to early-nineteenthcentury Sweden. ${ }^{10}$ However, once the economy improved in the mid1860s, this educational model was officially abandoned in elementary schools. Direct teacher instruction for every student was introduced, and in a significant departure from the Bell-Lancaster method, teachers were then expected to explain and demonstrate what was taught rather than to have their students merely repeat information without necessarily understanding it. This change is corroborated by a vast number of written recollections submitted by former students in elementary, intermediate, and college-preparatory schools. ${ }^{11}$ Indeed, what is common to most students' accounts of schooling is that their teachers engaged them with an authoritative and demanding yet vivid and lively approach from which the students learned knowledge and skills for a lifetime. ${ }^{12}$ This teaching

\footnotetext{
${ }^{8}$ At least, this was how the Bell-Lancaster method was practiced in the elementary schools for mass education, which the majority of children in Sweden attended. A less strict version of the monitorial system appears to have been used in the theoretical intermediate and college-preparatory schools (Larsson, 2016).

${ }^{9}$ Larsson (1953 [1931], p. 49).

${ }^{10}$ Andersson (1986, p. 39). One teacher, whose recollections were recorded in print, remembered teaching 112 pupils at one time (Thedéen, 1941).

${ }^{11}$ See Hall (1941).

${ }^{12}$ For example, a former pupil in elementary school reported of the teacher Anders Berg that he believed that "education must strive to support development of thinking"
} 
ideal was widely accepted and promoted in educational circles until the end of the 1950s. ${ }^{13}$

Alongside this innovation, students were systematically sorted into classes according to ability instead of all being congregated on long benches in the same large hall. Inside the new classrooms, the students were, for the first time, placed behind separate desks with space in between, which meant that "[e]ach student came to be distinguished from the mass ... and emerge as an individual." 14 This offered students the possibility of greater self-awareness and a means of cultivating selfregulation. Hence, there was a move away from the traditional view of discipline as synonymous with the imposition of external constraints and punishments. ${ }^{15}$ Instead, a more liberal conception of discipline as emanating from within the person took root in the educational system, and considerable value was placed on the inculcation of noncognitive skills such as attentiveness, conscientiousness, honesty, reliability, and perseverance. ${ }^{16}$ (Notably, the instillment of such character strengths was ultimately fundamental to Sweden becoming a universal welfare state. ${ }^{17}$ )

These and other changes to the school system were to a large extent, although not entirely, adopted from the pedagogical principles introduced by the early nineteenth-century German philosopher Johann Friedrich Herbart. ${ }^{18} \mathrm{He}$ believed that every child had an inner potential that could be realized through intellectual self-improvement and that the key to such realization was a structured and teacher-led education focused

and often said that "to read and not know is to plow and not sow" (Hall, 1941, p. 213). Another former pupil writes of his old teacher Alfred Dalin, "His instruction in history was animated and sparked interest. In particular, it gave him joy to open for us, workingclass children of a simple background, the gates to the antique world of gods and heroes" (p. 248). Yet another former pupil writes of the teacher Per Mauritz Sjöstrand, "The teacher threw all his energy into teaching and was always indefatigable in his efforts to teach and explain. ... I felt both lucky and happy to be able to learn that which I did not previously know. And the teacher did not hammer knowledge into the minds of the pupils ... he taught us" (p. 259; emphasis in original).

${ }^{13}$ Sjöberg (2014).

${ }^{14}$ Andersson (1986, p. 81).

${ }^{15}$ Within the next few decades, corporal punishment ceased to be practiced in most schools and stages (Qvarsebo, 2006).

${ }^{16}$ Andersson (1986, p. 82).

${ }^{17}$ Bergh and Björnskov (2011).

${ }^{18}$ Heller Sahlgren and Sanandaji (2019, p. 38) and Andersson (1986). 
on imparting knowledge. The idea was not that the students would mechanically follow the teachers' prescriptions but rather that they would internalize knowledge and learn to apply it by repetition and practice under the teacher's instruction and supervision, as was the case in Sweden, beginning in the 1860 s.

The Herbartian teaching ideal thus closely resembled modern pedagogical notions about the importance of the teacher, not as an agent of control or a mere "facilitator of learning" but as someone who leads the work in the classroom by virtue of his or her knowledge. ${ }^{19}$ Such an education, Herbart believed, would "protect the child from a game of chance" -in other words, from random environmental influences - and develop his or her ability to choose the "beautiful and good" over the "tasteless and unethical." 20 It was, in part, this idea that knowledge-rich instruction went hand in hand with the development of self-discipline and virtuous habits that led to the new forms of schooling in Sweden.

However, Herbart's pedagogy did not receive wide recognition until the German educator Tuiskon Ziller wrote about it in an influential work $^{21}$ and-together with his disciple Wilhelm Rein-developed it in even more practical and tangible ways. As a result, this educational philosophy came to be known as Herbart-Zillerism. In particular, Ziller added the notion that education must be adapted to the individual student's level of maturity and refined Herbart's thoughts about the planning of lessons. Herbart-Zillerism thus proposed five formal stages associated with teaching (which were meant to be followed flexibly rather than rigidly): (1) preparation - a process of arousing students' interest in a topic; (2) presentation-presenting new material in a concrete manner and rehearsing it with students; (3) association-through comparison and contrast with previously acquired knowledge; (4) generalization-a procedure especially important to the instruction of older students and designed to permit more abstract comprehension; and (5) applicationusing acquired knowledge so that it becomes part of the functional mind. "In this manner," Wilhelm Rein wrote, "a child's acquired idea may be so

\footnotetext{
${ }^{19}$ See, e.g., Biesta (2017) and Linderoth (2016).

${ }^{20}$ As cited in Siljander (2012, p. 96).

${ }^{21}$ Ziller (1865).
} 
developed, so welded together in firm, systematic, comprehensive association, that all his knowledge becomes a reliable, personal possession." 22 Compared to the Bell-Lancaster method, at least as it was practiced in Swedish elementary schools, Herbart-Zillerism was a giant theoretical leap forward in thinking about education and whom it should benefit.

The amalgamated philosophy of Herbart and Ziller quickly gained popularity in the mid-nineteenth century. It is noteworthy that it was keenly embraced in countries that would later, in the years leading up to World War I, become the scientifically and technologically most advanced societies, including Germany, Japan, the United Kingdom, and the United States. ${ }^{23}$ In Sweden, Herbart-Zillerism continued to exert significant influence over education in the last decades of the 1800s and after the turn of the century. ${ }^{24}$ One example of this continued influence is that Wilhelm Rein was invited to Stockholm in 1895 to give a series of pedagogical lectures to the Swedish educational establishment. The first truly national curriculum, which was enacted in 1919 and remained in effect until $1955,{ }^{25}$ also clearly reflected the Herbart-Zillerist approach by emphasizing genuine content mastery through teacher-led presentation, repetition, and practice and by matching the sequence of topics to the student's maturity and prior knowledge. The whole structure of the curriculum was in keeping with Rein's point, made in one of his lectures in Sweden, that " $[t]$ he new thought material must be anticipated by the old, and the previously imparted knowledge must be retained in order to be able to receive the new." 26 According to the curriculum, the goal of such an instruction- and repetition-based educational process was to make "the children's progress apparent to themselves and instill a joy of work." 27

The Herbartian moral philosophy of education, in which knowledge is envisioned to enhance the individual's character, also remained embedded

${ }^{22}$ As cited in Da Garmo (1895, p. 137).

${ }^{23}$ For a description of how this type of pedagogy was implemented in the United States, see, e.g., Dunkel (1969a, 1969b). Herbart's influence on the development of Japanese education is discussed in Duke (2009).

${ }^{24}$ Heller Sahlgren and Sanandaji (2019) and Jedemark (2007).

${ }^{25}$ Swedish National Board of Education (1920).

${ }^{26}$ As cited in Kaleen $(1979$, p. 70$)$. See also Kilpatrick and Johansson (1994, p. 11) on this point.

${ }^{27}$ Swedish National Board of Education (1920, p. 50). 
in the Swedish educational system. An emblematic example is a 1954 civics textbook for elementary school in which the point is repeatedly made that knowledge is the key to a life well lived and being a person of integrity and substance. ${ }^{28}$ For instance, in a moralizing short story in the book, a father warns his son, who wants to quit his education to go into farming, that "a farmer needs plenty of knowledge-in biology and chemistry, for instance-in order to become something of worth" and not remain an order-taking "stooge" all his life. ${ }^{29}$ Another short story conveyed, in a moving narrative, the benefits and character-building aspects of completing a Ph.D. degree. The latter is quite remarkable considering that the textbook, as mentioned, was intended for use in elementary education. Many children in Sweden at this time, particularly those from poor families or who lived in remote rural municipalities, expected the six-year elementary education to be the only formal schooling that they would receive before entering working life; however, all students were taught that the option of pursuing theoretical studies was both virtuous and available to them.

At the same time, conditions were changing, and participation in higher learning was increasing. After World War II, "the numbers of students continuing past the first six years exploded," 30 and a considerably larger share of every age group went on to the theoretical intermediate school (the realskola) and the college-preparatory school (the läroverk) within Sweden's parallel schooling system, ${ }^{31}$ which had a liberal arts curriculum and was of exceptional educational quality. ${ }^{32}$ It has been noted that "[i]n $19299 \%$ of the age group continued in the realskola; by the

${ }^{28}$ Rosén and Jonsson (1954).

${ }^{29}$ Rosén and Jonsson (1954, p. 88).

${ }^{30}$ Lidström (2015, p. 73$)$.

${ }^{31}$ Before 1962, education after elementary school (folkskola) was divided into two separate, voluntary tracks: (i) intermediate school (realskola), which could be followed by college-preparatory school (läroverk), and (ii) vocational schooling.

${ }^{32}$ Syllabi and examination questions in the läroverk, which have been preserved in facsimile (Thorén, 1963), show that the education provided in the college-preparatory school was of an extraordinarily high standard. Even as late as 1957, some of the questions for the higher certificate examination (the studentexamen) invite comparison to the highly competitive test for admission to the diplomatic training program in the Swedish Ministry of Foreign Affairs. 
end of the fifties it exceeded 40\%." 33 Similarly, enrollment at the collegepreparatory level "increased from 17,000 in 1945 to 63,000 in 1962."34 This educational "explosion" was an effect of increasing prosperity, ${ }^{35}$ which allowed a much larger and more diverse portion of the population to advance in the educational system. Many parents in the working and lower middle classes understandably jumped at the opportunity for their children to more easily acquire further knowledge that had been hard-won by themselves only through correspondence courses and other means of self-education. ${ }^{36}$

The theoretical intermediate school was, however, not equipped to handle the growing numbers of students and became strained under the pressure of the sharply increased demand. An expansion of the number of places would likely have been possible, but, as several scholars have noted, ${ }^{37}$ the Social Democratic government at the time considered it a problem that so many chose theoretical studies and opted for another solution. In the early 1960s, the old parallel schooling system was abolished, and the so-called unity school, in which all children would study together for nine years, was enacted. As we discuss later in this book, the unity school did not have the same orientation toward knowledge and rigorous academic standards. Consequently, it did not value its teachers as highly as the previous educational system had.

\section{The Teachers}

The educational trend of Herbart-Zillerism, with its emphasis on the importance of the teacher in the learning process, influenced the selection and training of teacher candidates in Sweden in the late nineteenth and early twentieth centuries. ${ }^{38}$ The state went to enormous lengths to ensure that teachers were qualified for their task of providing instruction

\footnotetext{
${ }^{33}$ Spolton (1967, p. 156).

${ }^{34}$ Spolton (1967, p. 156). In percentage terms, this means that enrollment at the college-preparatory level rose from six percent of the relevant age cohorts in 1945 to approximately 21 percent in 1962.

${ }^{35}$ Hadenius (1990).

${ }^{36}$ Ohrlander (1981).

${ }^{37}$ See, e.g., Hadenius (1990) and Richardson (1978) on this point.

${ }^{38}$ Jedemark (2007) and Kaleen (1979).
} 
and setting an example for their students. The demands on intellectual agility were high, and only the best were admitted into the profession. ${ }^{39}$ Before starting their teaching career, people underwent seven demanding years of realskola and college-preparatory school plus at least three and a half years at the university. Indeed, as in neighboring Finland, where Herbart-Zillerism had also taken root in the educational system at the time, "[t] eachers were supposed to be model citizens." 40 When applying for a teaching position in an elementary school, teachers were ranked according to merit and experience in competition with others, similar to how university positions are filled today. They were sometimes also required to give trial lectures. ${ }^{41}$

The rigorous training that took place in teacher seminars, which included many practical exercises in Herbart-Zillerist pedagogy, contributed to the emergence of a professional ethos that became a significant motivating factor for Swedish teachers. ${ }^{42}$ Virtues such as duty, engagement, and self-sacrifice formed the core of this ethos, and teachers consequently saw themselves as public servants committed to an ideal of service above self. They even dressed the part, as is evident in photographs of impeccably groomed teachers accompanying birthday eulogies and obituaries published in old teachers' journals from before and after World War II. The latter described deceased teachers as fallen warriors in a kind of culture war against ignorance and oblivion.

The extrinsic reward in the form of salary was not considered as important. ${ }^{43}$ In an emblematic formulation of the professional ethos of teaching, Alfred Fridén, a Swedish teacher and school inspector in the early 1900s, wrote, "Other [professional] avenues may offer more gold and a more comfortable existence ... however, nothing of that belongs to what matters in life, to that which is of lasting worth." 44

${ }^{39}$ Sjöberg (2006b).

${ }^{40}$ Paksuniemi, Määttä, and Uusiautti (2013, p. 1).

${ }^{41}$ Sjöberg (2010).

${ }^{42}$ Sjöberg (2006a, 2006b) and Wennström (2016).

${ }^{43}$ In this context, it is noteworthy that the relative wage of teachers at the time was high (Ljungberg, 2013). For further details on this issue, see Chapter 4.

${ }^{44}$ Cited in Sjöberg (2014, p. 127). 
In the terms of the U.S. political scientist James Q. Wilson's analysis of public professions, ${ }^{45}$ the ethos of Swedish teachers provided them with an intensely felt "sense of mission." This meant that teachers, as has typically been the case for physicians, police officers, and scholars, could be trusted to perform to the best of their abilities without supervision or codified rules. ${ }^{46}$ Hence, Swedish teachers had considerable autonomy in their work and were, for instance, not obligated to be present at the school where they taught during nonteaching hours. Indeed, it was widely understood that " $[\mathrm{t}]$ he teacher needed much free time in order to improve him- or herself. A teacher was expected to think and read a lot, and not least reflect on his or her students and teaching methods, prepare lessons, and find new pedagogical approaches." 47 Teachers' commitment to their task was simply taken for granted, and there was no perceived need for bureaucratic interference.

Thus, during "the silver age" of Swedish education, teaching was not just an occupation but a vocation that was separate and different from ordinary paid work and was considered to be more important than the individual. This selfless dedication to knowledge and education, which was strongly encouraged by the Swedish state, brought teachers respect and social esteem. Together with the professional freedom of teaching, the high status that teachers enjoyed in society attracted some extremely talented individuals to the profession.

\section{IN SUM}

As we noted in Chapter 1, Sweden went from being one of the poorest countries in Europe to one of the three richest by the mid-1960s. ${ }^{48}$ As for any country that has gone from being backward to becoming rich and technologically advanced, this advancement would not have been possible without the development of a high-quality educational system. This resulted in both a high general level of education in the population at large for its time and world-class college-preparatory schools that gathered the most academically gifted students and put them on a track

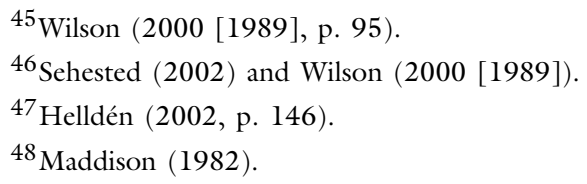


for future positions as leading scientists, technicians, entrepreneurs, and managers.

We have shown in this chapter how Sweden developed such a highquality educational system beginning around 1860 and how that system gradually evolved so that an increasing share of young cohorts were offered excellent educational opportunities. After World War I, a truly national curriculum was introduced that imparted relevant knowledge and skills to students based on the principles of teacher-led presentation, repetition, and practice and by matching the sequence of topics to each student's maturity and prior knowledge.

A significant part of the success of this system must be ascribed to the teachers. A key element in the modernization of the educational system was the state's preoccupation with ensuring that highly qualified and motivated persons were attracted to the teaching profession. Teacher training was rigorous and contributed greatly to the emergence of a forceful professional ethos that turned teaching into a vocation rather than an occupation. As a result, teachers were allowed considerable autonomy in their work. Their sense of mission also functioned as an important source of inspiration for students to become equally competent and develop important noncognitive skills, such as reliability and perseverance.

Open Access This chapter is licensed under the terms of the Creative Commons Attribution 4.0 International License (http://creativecommons.org/licenses/ by $/ 4.0 /$ ), which permits use, sharing, adaptation, distribution and reproduction in any medium or format, as long as you give appropriate credit to the original author(s) and the source, provide a link to the Creative Commons license and indicate if changes were made.

The images or other third party material in this chapter are included in the chapter's Creative Commons license, unless indicated otherwise in a credit line to the material. If material is not included in the chapter's Creative Commons license and your intended use is not permitted by statutory regulation or exceeds the permitted use, you will need to obtain permission directly from the copyright holder.

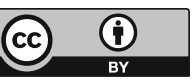

